\title{
有機半導体のグラフォエピタキシーとキャリア輸送
}

\author{
池田進 \\ 東北大学原子分子材料科学高等研究機構（WPI-AIMR） 事980-8577 宮城県仙台市青葉区片平 2 丁目 1-1
}

（2013 年 12 月 10 日受付；2014 年 1 月 15 日揭載決定）

\section{Graphoepitaxy of Organic Semiconductors and Improvement of Carrier Transport}

\author{
Susumu IKEDA
}

WPI-Advanced Institute for Materials Research (AIMR), Tohoku University, 2-1-1 Katahira, Aoba-ku, Sendai, Miyagi 980-8577

(Received December 10, 2013 ; Accepted January 15, 2014)

\begin{abstract}
Controlling in-plane orientation and obtaining single-crystalline thin films are among the important factors to improve the carrier transport in organic thin film transistors (TFTs). Since the surface of the substrate is often amorphous in organic TFTs, epitaxial growth technique is not applicable to control the orientation of the thin films. This article focuses on graphoepitaxy as the technique to control the in-plane orientation of organic thin films and improve the carrier transport. While graphoepitaxy has been studied nearly forty years in inorganic materials, graphoepitaxy of organic materials shows novel and peculiar characteristics which are not observed in inorganic systems. Organic graphoepitaxy is not a mere diversion of old technique but a phenomenon which derives new aspects and possibility from organic materials.
\end{abstract}

KEYWORDS : graphoepitaxy, organic semiconductor, in-plane orientation, thin film transistor, carrier transport

\section{1.は じめに}

有機半導体デバイスは学際融合的な研究分野であり, 有機化学のみならず, 固体物理, 特に半導体物理, 結晶 成長, デバイス工学, またさらに全素子・回路を印刷で 作製しうるという特徴から印刷技術なども含む様々な分 野の研究者の協力によって成り立っている。そして, そ の学際・融合の中で忘れてはならないのが表面科学の寄 与である。キャリア伝導路としての有機半導体/ゲート 絶縁体界面, キャリア注入の場である有機半導体/金属 (電極）界面ほか表面・界面があちこちに存在し, 表面 科学の知識, 技術が不可欠である。また, 本稿のテーマ であるが，高品質の薄膜成長技術は，やはり表面科学が 貢献できる課題である。本稿では, 有機半導体のグラフ オエピタキシーについて, 既に発表している解説 ${ }^{1,2)}$ と は少し異なった視点で, 本研究の出発点, キャリア輸送 改善に関する最近の発展, 今後の課題や可能性なども織 り交ぜ解説したい。

E-mail : sikeda@m.tohoku.ac.jp
私的な話になるが，筆者らがグラフォエピタキシーの 研究に着手した，その始まりの部分を書かせていただ く。表面科学の研究室で得たエピタキシーによる高品質 薄膜成長の知識や技術を有機半導体薄膜の品質向上に応 用しようと，筆者がこの分野の研究を始めたのは 2002 年頃である。その頃有機半導体分野は既に急成長を遂 げ, たとえば, 有機 EL などは実用化, 商品化の域に達 していた。研究者は全有機デバイスを実現するために, 有機半導体を用いた電界効果トランジスタ（有機 FET） の研究を進め, 単結晶では $10 \mathrm{~cm}^{2} / \mathrm{Vs}$ を超える移動度が 達成されるなど，日々新たな知見が報じられていた。し かしながら, 実用化においては作製プロセスの観点から 薄膜の FET（TFT）が主力となるため, 薄膜で高い移動 度を得る必要があるが，そのような高品質の薄膜を作製 する技術が確立されず，これが有機 FET の実用化を妨 げる高いハードルとなっていた。通常の薄膜作製法で は, 多結晶膜, しかも面内方位ランダムな多結晶薄膜に なることが多く, 粒界等によってキャリア輸送が阻害さ れるためである ${ }^{3,4)}$ ここのうな背景から, エピタキシ 一等の技術を用いて単結晶的薄膜作製を可能にする技術 
開発が急務となっており，筆者もその方向性に興味を持 ってこの分野に参入させていただいたのである。

筆者が在籍していた研究室 (斉木研) では, 高速電子 線回折（RHEED）等で結晶性のその場観察を行いなが らエピタキシャル成長の実験をする装置, 技術を有して いた。筆者は比較的高い移動度が報告されていた $\alpha$-セ クシチオフェン ( $\alpha$-sexithiophene : 以降 $\alpha$-6T と称す) を 研究対象とし, この有機半導体を超高真空槽の蒸発セル に詰め, 水晶振動子によって成長速度を確認しながら, さらに基板温度も調整し, 単結晶的な薄膜を得ようとし た。基板としては，最初にアルカリハライド（KBr）を 使用した。比較的高い基板温度, 非常にゆっくりとした 成長速度のときに RHEED で面内選択配向した兆候が得 られ，その試料を真空装置から取り出して微小角入射 $\mathrm{X}$ 線回折（GIXD）に供し面内方位を測定したところ，明 らかに面内選択配向していることが確認できた。ところ が, 基板と有機半導体の結晶構造，および方位関係を検 討すると，格子整合性に基づくエピタキシャル成長では 説明がつかず，原子間力顕微鏡（AFM）を用いて薄膜 の形態を入念に調べ，多くの結晶ドメインが基板表面の 〈100〉方向のステップに沿って成長していることから， step-induced のエピタキシャル成長（基板のステップに 対して核形成し，ステップによって方位が規定される） が起こっているものと結論し, 2004 年に論文発表し た ${ }^{5)}$ 。これが筆者の，基板表面形状によって面内選択配 向する現象を観測した最初の経験となった。その後，和 田恭雄教授（当時早稲田大学）と電子線リソグラフィー による微細電極を用いた共同研究が始まった際に, 和田 教授よりグラフォエピタキシーの概念を教示いただき, 研究提案を受けた。上述の step-induced エピタキシーを 経験していた筆者はその有効性を感じ, 早速, 有機半導 体のグラフォエピタキシーの研究に着手した。和田グル ープが電子線リソグラフィーによる微細加工基板の作製 を担当，筆者らがその基板を用いて有機薄膜の成長と評 価を担当する共同研究が開始された。

\section{2. グラフォエピタキシー}

\section{1 有機薄膜の結晶方位制御}

有機薄膜のエピタキシーについては，芦田らが雲母や アルカリハライドの基板上に成長させた金属フタロシア ニン薄膜の構造を透過型電子顕微鏡（電子線回折）で解 析したのが，基板と薄膜の間の明確なエピタキシャル方 位関係を示した最初の報告であると思われる6,7)。また より近年に扔いては, 小間らが精密なエピタキシャル成 長技術を応用して研究を行い, 基板結晶格子との弱い相 互作用に基づくファンデルワールス・エピタキシーの概

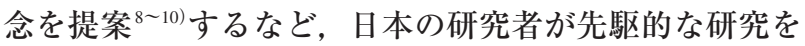
行っていた。このように, 成長基板として単結晶を用い ることができればエピタキシーにより単結晶的薄膜を得 ることが可能であるが，基板が非晶質の場合，この技術 を直接適用することはできない。実際のデバイスでは, 非晶質のゲート絶縁膜上に半導体を成長させることが多 く，そのようなデバイス特有の制約条件の中で面内方位 制御された薄膜を成長させるためには何らかの工夫が必 要である。興味深い方法として, 摩擦転写法によりフッ 素樹脂の配向膜を基板上に予め塗布しておき，その上に 低分子の有機半導体薄膜を成長させる方法 ${ }^{11}$ や，基板表 面を光配向ポリイミドで被覆し，その上に低分子有機半 導体を成長させる方法 ${ }^{12}$ などが提案されている。

\section{2 グラフォエピタキシー}

無機材料の分野では, 非晶質基板上の面内方位制御法 として, 1970 年代からグラフォエピタキシーが検討さ れてきた。この現象は最初ソビエト連邦 (当時) の研究 者によってその兆候が見いだされ ${ }^{13)}$, その後マサチュー セッツ工科大学 (MIT) の H.I. Smith らが系統的に研究 し適用範囲を広げ，アモルファス基板上での新たな結晶

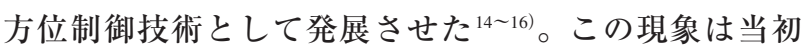
Artificial epitaxy と呼ばれていたが, 1979 年に MIT グル ープが論文にグラフォエピタキシー（Graphoepitaxy）と いう名前を記載, 提案し ${ }^{15)}$, それが定着した。文献 ${ }^{15)} に$ よれば，ギリシャ語で「書く，刻む，彫刻する」を意味 する“grapho”，「〜の上で」を意味する “epi”，「配列， 秩序」を意味する “taxis”の組み合わせで Graphoepitaxy となっている。人工的に刻んだ構造上での秩序配列 を意味している。近年ではブロックコポリマーやコロイ ド粒子の配列制御にも応用されている ${ }^{17)}$ 。

「有機半導体のグラフォエピタキシー」には単結晶表 面の原子ステップ（複数層のステップが束になった bunched step も含む) を利用したもの ${ }^{18-20)} も$ 含めること が多くなっているが，本稿では，無機材料分野で研究が 進められたリソグラフィー等による人工構造に対する擬 似的なエピタキシーを指すこととしたい。

グラフォエピタキシーのメカニズムに関しては未だに 議論が続いているが，Fig. 1 に示すように，溝のエッジ で核形成する際に方位が規定されるケース，結晶が成長 する過程で溝の形に結晶面がうまくフィットするように 結晶が面内回転して方位が規定されるケース，その両方 が関与するケースの三つのケースがあると考えられてい る ${ }^{16)}$ 。有機半導体のグラフォエピタキシーのメカニズム もこれに類すると考えられる。現れる結晶面, 結晶の外 形が配向方位に影響を及ぼすのは明らかなようで，たと えば $\{111\}$ 面等が現れやすい結晶の場合，エッジが垂直 


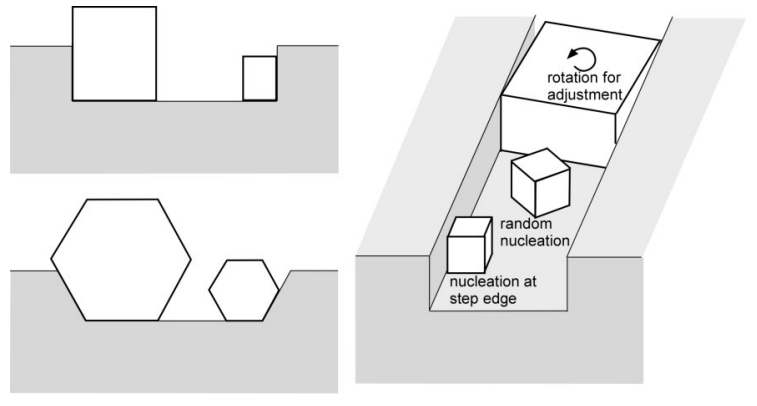

Fig. 1. Schematic illustration showing the concept and suggested mechanism of graphoepitaxy.

に切り立った溝よりも, 斜めに掘られた溝の方が適して いるなどの実験事実も知られている ${ }^{13,21)}$ 。

\section{3 有機薄膜のグラフォエピタキシー}

前述のとおり, グラフォエピタキシーは無機材料系で 1970 年代に見いだされ 40 年に及ぶ研究の歴史がある が，ここでは無機材料のグラフォエピタキシーとは異な る, 有機材料系に特有の現象に注目し研究紹介したい。 有機材料では対称性が低く異方性の大きい物質が多く, これが有機特有のグラフォエピタキシー現象を生み出す ようである。

ではここで再び話を $\alpha-6 \mathrm{~T}$ に戻し, 研究の時系列に従 い紹介する。使用した基板は厚さ $200 \mathrm{~nm}$ の熱酸化膜が 付いたシリコン（100）基板であり, 電子線リソグラフ イーとドライエッチングによって, 溝の幅 $200 \mathrm{~nm}$, 丘 の幅 $200 \mathrm{~nm}$ ，ピッチ $400 \mathrm{~nm}$ の矩形の周期的な溝を作製 した。この基板を有機溶媒で洗浄の後，UV/オゾンクリ ーナーで表面清浄化をした。この段階で基板表面は親水 性となっている。この基板をエピタキシャル成長害験用 の超高真空槽（ベース真空度 $2 \times 10^{-7} \mathrm{~Pa}$ 前後）に導入 し, 基板温度 $110^{\circ} \mathrm{C}$, 成長速度 $0.13 \mathrm{~nm} /$ 分程度の条件で 薄膜を成長させた。

得られた薄膜の評価には AFM と GIXDを用いた。こ の親水性の基板上では, 複数の結晶が連結したドメイン が溝の方向に一次元的に伸長するような成長様式が観察 された（Fig.2（a)）22)。面内方位については，GIXD に よる膜全体の平均化データと, AFM 画像を用いて判定 した個々の結晶の方位頻度分布を照らし合わせ， $\alpha-6 \mathrm{~T}$ 結晶の $b$ 軸が溝に平行なものの割合が多いことを導き出 した。さらに興味深いのが，基板表面をへキサメチルジ シラザン（HMDS）により疎水化処理した場合の結果で ある。Fig. 2（b）抒よび2（c）に示すように，面内方 位の様相は親水性基板の場合と大きく異なり, $b$ 軸が溝 に垂直， $c$ 軸が溝に平行（すなわち， $90^{\circ}$ 面内回転した 形）となった ${ }^{23)}$ 。詳しくは解説記事 ${ }^{2}$ p原著論文 ${ }^{23)}$ 等を

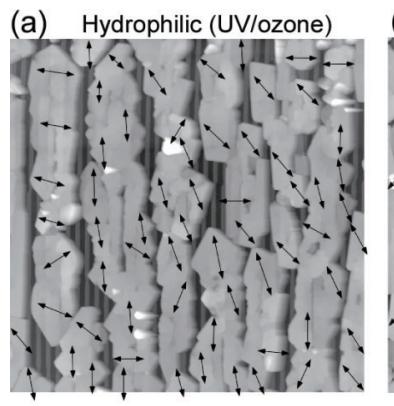

(b) Hydrophobic (HMDS)

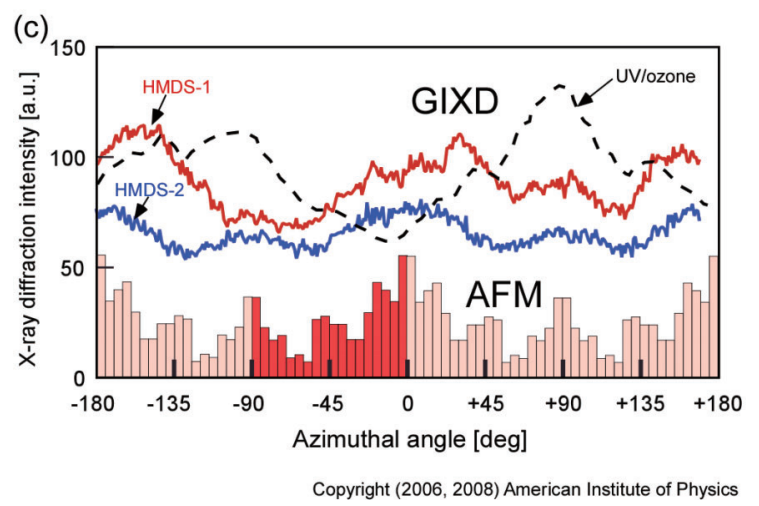

Fig. 2. (color online). (a, b) AFM topographic images of $\alpha$ $6 \mathrm{~T}$ thin films grown on periodically microgrooved surface. Each arrow indicates the $b$-axis direction of each crystal grain. (c) Comparison of GIXD data with the histogram of grain orientation measured by AFM. Reproduced from references 22 and 23 with the permission of American Institute of Physics.

参照いただきたいが，これは， $\alpha-6 \mathrm{~T}$ 結晶の異方性に起 因していると考えられる。すなわち，溝の壁面の化学状 態（表面を終端している官能基）が変わると，溝壁面と の相互作用がより安定化されるような結晶面が溝壁面と 接するようになり, 結晶方位が変化することを示唆して いる。有機材料は一般に結晶の対称性が低く, 異方性が 大きいため, このような基板表面との微妙な相互作用の 結果，このような方位変化が起こるのであろう。無機材 料では対称性の高い結晶が多いため，このような現象が 顕著に見られなかったのかもしれない。基板上に親水性 領域と疎水性領域を作り分けることは可能であるので, 領域ごとに面内配向方位を制御するような応用もできそ うである。

ここでもう一つ紹介したいのは, 電極エッジによる方 位制御の可能性である ${ }^{24)}$ 。Fig. 3 はフォトリソグラフィ 一で作製した電極（中央に見える窪みがチャネル部分, すなわちソース・ドレイン電極の切れ目）近傍での $\alpha$ 6T の成長を示している。チャネルの底（電極エッジに は接していない部分) で方位が規定されず核形成した結 晶ドメインは，そのままの方位で電極上（図の左側）へ 
と這い上がり成長してしまっているが，電極のエッジで 核形成したドメイン（図の右側）はエッジに対して $b$ 軸 が垂直となる方位をもって成長している。このような, 方位が定まった結晶がチャネルを埋め尽くせば，チャネ ルの結晶方位がすべて揃った理想的なデバイスを実現で きる可能性がある。電極はデバイスに必須の要素であ り，この技術が応用可能であれば，本稿前半で示したよ うな周期的な溝構造などを敢えて作製する必要はなくな るかもしれない。

\section{4 トランジスタ性能の改善}

前節までに，グラフォエピタキシーによる有機半導体

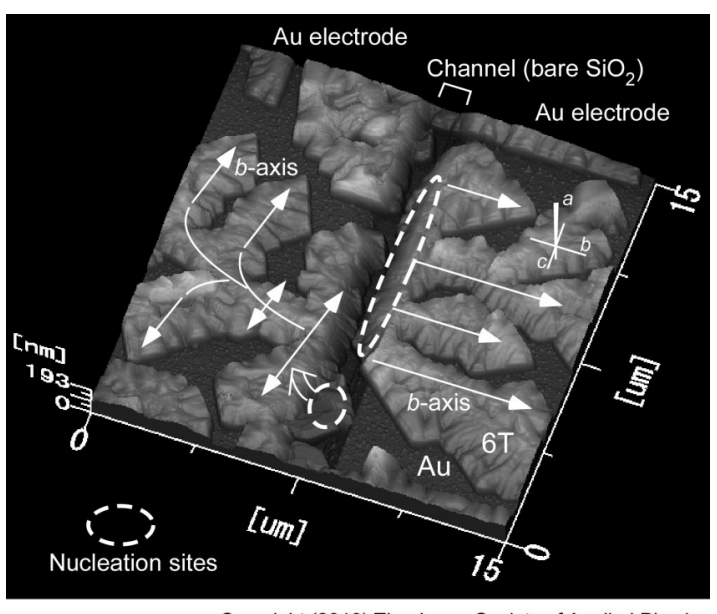

Copyright (2010) The Japan Society of Applied Physics

Fig. 3. Crystal domains of $\alpha-6 \mathrm{~T}$ grown around the edge of gold electrodes fabricated by photolithography. Reproduced from reference 24 with the permission of the Japan Society of Applied Physics.

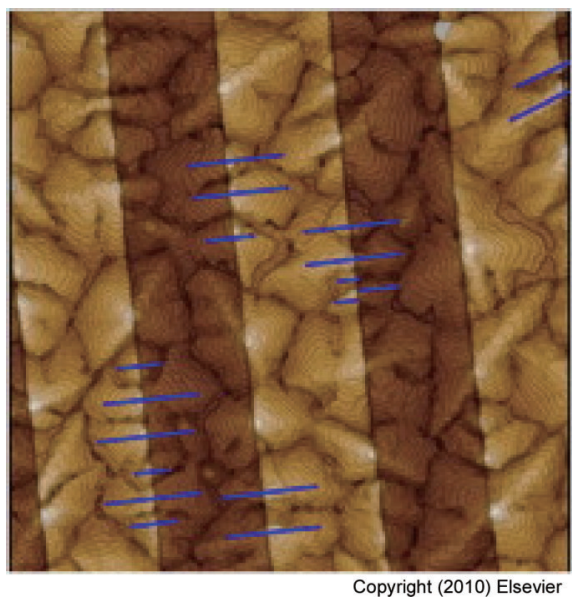

Fig. 4. (color online). AFM image of a pentacene thin film grown on a patterned substrate. Blue lines indicate parallel inplane orientation of the pentacene grains. Reproduced from reference 27 (S.-G. Li et al.) with the permission of Elsevier.
の面内方位制御に関して解説を行ったが，ここでは，そ の方位制御がキャリア輸送の改善に寄与できることを示 したい。Fig. 2 (a) に見られるような，一次元的に連結 したドメイン内では粒界抵抗も小さく, 移動度改善に資 する可能性が示唆されている ${ }^{25)}$ 。では, FET デバイスと してはどうであろうか。これまでにいくつかの研究グル ープがグラフォエピタキシーによる薄膜品質改善に取り 組み，キャリア移動度の向上にも成功している ${ }^{26-28) 。 ~}$

Fig. 4 は周期的な溝構造上にペンタセンを分子線蒸着 させた薄膜の AFM 像であり, ペンタセン結晶粒の形状 から方位を決定した奈良先端大・千葉大グループの研究 結果であるが，面内配向の制御に成功し，その結果キャ リア（正孔）移動度も10２0\% 上昇したことが報告さ れている ${ }^{27)}$

\section{3. 今後の課題}

グラフォエピタキシーの問題は, 基板と薄膜の結晶格 子間の整合性に基づく本来のエピタキシーと異なり，原 子レベルの正確さがないこと，すなわち，分子からすれ ば，リソグラフィーによる溝や壁は途方もなく大きな構 造であり, 基板の微細構造の乱れによって個々の結晶ド メインの方位や位相にずれが生じ，ドメイン間の合体が 思ったほど進まないことである。成長後のアニールなど はこの問題の改善に有効ではあるが, エピタキシーと同 様に原子・分子レベルで制御していくためにはどうすれ ばよいかを検討していく必要がある。

そのためにも，グラフォエピタキシーの原子・分子レ ベルでのメカニズムを解明していく必要がある。その第 一歩として, たとえば分子動力学 (MD) シミュレーシ ヨンによる考察などを進めることも必要であろう。Fig. 5 は MD シミュレーションの予備的な計算結果である。 多数の $\alpha-6 \mathrm{~T}$ 分子（剛体仮定）を金の結晶表面付近に配 置し，分子間，分子-金原子間にはレナード・ジョーン ズ型ポテンシャルを適用してシミュレーションを行っ た。図はある時刻の状態を二つの方向から眺めたもので
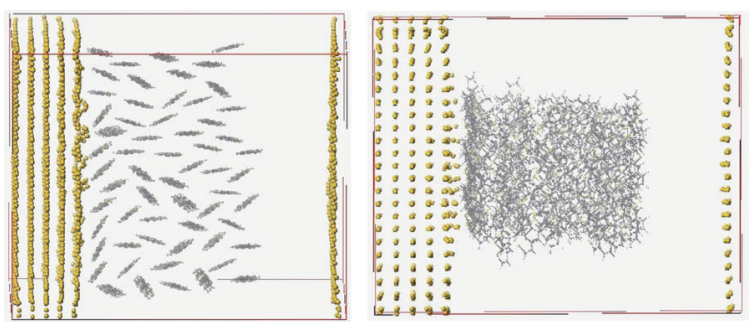

Fig. 5. (color online). Preliminary result of molecular dynamics simulation of $\alpha$-6T molecules on gold surface. Two shots from different angles are shown. 


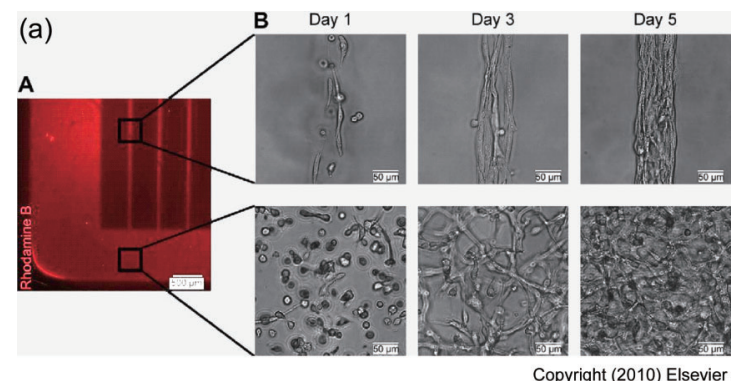

(b)

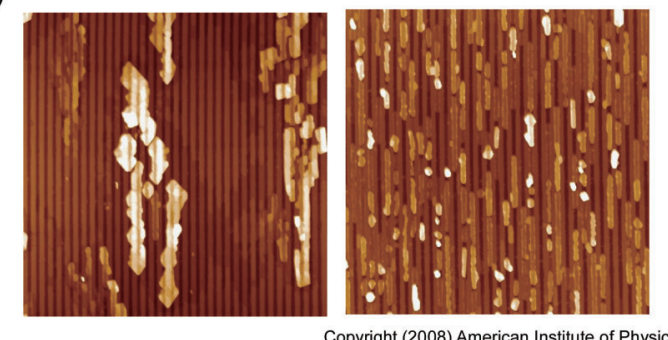

Fig. 6. (color online). (a) Cell morphology and organization as a function of time in patterned and unpatterned microconstructs. Cellular alignment and elongation were induced in the patterned hydrogels, while cellular orientation in unpatterned one remained random. Reproduced from reference 29 (H. Aubin $e t a l$.) with the permission of Elsevier. (b) AFM images of the $\alpha$-6T thin films grown on microgrooved hydrophilic (left) and hydrophobic (right) substrates. Reproduced from references 22 and 23 with the permission of American Institute of Physics.

あるが, 左の図を見ると, ヘリングボーン構造をとって おり, 分子間のポテンシャルはお拈よそ適切なものが用 いられていると考えられる。このようなシミュレーショ ンを行うことで, たとえば, 親水性, 疎水性基板で見ら れたような, 基板表面の化学状態に基づく薄膜の方位変 化等に関しても解明ができ, より精度の高いグラフォエ ピタキシーを実現するための指針が得られるものと期待 される。

最後に話が脇道に逸れてしまうが, 筆者が最近興味を 持っているのは, 生体材料との類似性である。Fig. 6 (a) は A. Khademhosseini (Harvard-MIT’s Division of HST 准教授, WPI-AIMR 主任研究者）らの研究結果であり, 空間的な制約のない環境の場合, 細胞がランダムな成長 をするのに対し, 太さ 100 ミクロン程度の管状の空間で 培養すると，管に沿った組織を作る様子を示してい る ${ }^{29)}$ 。非生物である $\alpha-6 \mathrm{~T}$ が結晶成長によって作る組織 （Fig.6（b））とよく似ている。細胞や組織発展のメカニ ズムと非生物材料の結晶成長のこの類似性を見ている と, 生体材料と非生物有機材料を結合した新しい夕イプ のデバイスも可能ではないかと, 漠然とではあるが考え ている。

\section{4. ま め}

有機半導体のグラフォエピタキシーについて, 研究経 緯と結果の概要, キャリア輸送に関する最近の発展, 今 後の課題や可能性について述べた。現象としては既に知 られていた無機材料のグラフォエピタキシーの応用とし て始まった研究ではあるが, それとは異なる新しい科学 を楽しめる分野であることがわかってきた。

今回は単著で書かせていただきましたが，本稿で示し た結果は多くの方々との共同研究の成果であり, 特に和 田恭雄教授 (早稲田大学, 東洋大学), 斉木幸一朗教授 (東京大学) のご指導, ご支援がなければ進まないもの でした。ここに記して感謝の意を表します。

\section{文 献}

1) 池田 進, 和田恭雄, 島田敏宏, 齐木幸一朗 : 真空 $\mathbf{5 0}$, 729 (2007).

2) 池田 進, 和田恭雄, 稲葉克彦, 寺嶋和夫, 島田敏宏, 斉木幸一朗 : 日本結晶成長学会誌 35, 243 (2008).

3) A.B. Chwang and C.D. Frisbie : J. Appl. Phys. 90, 1342 (2001).

4) M. Nakamura, H. Ohguri, N. Goto, H. Tomii, M. Xu, T. Miyamoto, R. Matsubara, N. Ohashi, M. Sakai and K. Kudo : Appl. Phys. A 95, 73 (2009).

5) S. Ikeda, M. Kiguchi, Y. Yoshida, K. Yase, T. Mitsunaga, K. Inaba and K. Saiki : J. Cryst. Growth 265, 296 (2004).

6) E. Suito, N. Uyeda and M. Ashida: Nature 194, 273 (1962)

7) M. Ashida : Bull. Chem. Soc. Jpn. 39, 2632 (1966).

8) A. Koma : Thin Solid Films 216, 72 (1992).

9) A. Koma : Prog. Cryst. Growth Charact. Mater. 30, 129 (1995).

10) URL : http://van-der-waals-epitaxy.info/

11) Y. Ueda, M. Matsushita, S. Morimoto, J.P. Ni, H. Suzuki and S. Mashiko: Thin Solid Films 331, 216 (1998).

12) D. Guo, K. Sakamoto, K. Miki, S. Ikeda and K. Saiki : Phys. Rev. Lett. 101, 236103 (2008).

13) E.I. Givargizov : J. Cryst. Growth 310, 1686 (2008).

14) H.I. Smith and D.C. Flanders : Appl. Phys. Lett. 32, 349 (1978).

15) M.W. Geis, D.C. Flanders and H.I. Smith : Appl. Phys. Lett. 35, 71 (1979).

16) H.I. Smith, M.W. Geis, C.V. Thompson and H.A. Atwater : J. Cryst. Growth 63, 527 (1983).

17) J.Y. Cheng, C.A. Ross, H.I. Smith and E.L. Thomas : Adv. Mater. 18, 2505 (2006).

18) M. Nakamura, T. Matsunobe and H. Tokumoto : J. Appl. Phys. 89, 7860 (2001).

19) V. Ignatescu, J.-C.M. Hsu, A.C. Mayer, J.M. Blakely and G.G. Malliaras : Appl. Phys. Lett. 89, 253116 (2006).

20) T. Shimada, M. Ohtomo, T. Suzuki, T. Hasegawa, K. Ueno, S. Ikeda, K. Saiki, M. Sasaki and K. Inaba : Appl. Phys. Lett. 93, 223303 (2008). 
21) A.L. Giermann and C.V. Thompson : Appl. Phys. Lett. 86, 121903 (2005).

22) S. Ikeda, K. Saiki, K. Tsutsui, T. Edura, Y. Wada, H. Miyazoe, K. Terashima, K. Inaba, T. Mitsunaga and T. Shimada : Appl. Phys. Lett. 88, 251905 (2006).

23) S. Ikeda, K. Saiki, Y. Wada, K. Inaba, Y. Ito, H. Kikuchi, K. Terashima and T. Shimada: J. Appl. Phys. 103, 084313 (2008).

24) S. Ikeda, Y. Wada and K. Saiki : Jpn. J. Appl. Phys. 49, 04DK19 (2010).

25) S. Ikeda, Y. Wada, K. Inaba, K. Terashima, T. Shimada and K. Saiki : Mater. Res. Soc. Symp. Proc. 1059, KK11-
11 (2008).

26) M. Xu, M. Nakamura, M. Sakai and K. Kudo: Adv. Mater. 19, 371 (2007).

27) S.-G. Li, N. Nakayama, M. Sakai, K. Kudo, R. Matsubara and M. Nakamura: Org. Electron. 13, 864 (2012).

28) S.J. Jo, C.S. Kim, M.J. Lee, J.B. Kim, S.Y. Ryu, J.H. Noh, K. Ihm, H.K. Baik and Y.S. Kim : Adv. Mater. 20, 1146 (2008).

29) H. Aubin, J.W. Nichol, C.B. Hutson, H. Bae, A.L. Sieminski, D.M. Cropek, P. Akhyari and A. Khademhosseini : Biomaterials 31, 6941 (2010). 